\title{
ASSESSMENT OF EMOTIONAL AND BEHAVIOUR DISORDERS OF GIRLS LIVING IN RESTRICTED ENVIRONMENT AND INTERVENTION STRATEGIES THROUGH PHYSICAL ACTIVITY
}

\author{
Diana Rèklaitienè, Aida Gaižauskienė, Vida Ostasevičienė, Jūratė Požèrienė \\ Lithuanian Sports University, Kaunas, Lithuania
}

\begin{abstract}
Background. Students with emotional and behavioural disorders (EBD) represent one of the most challenging groups not only to provide effective educational services, but often present complex challenges for schools, families, and society. There is a lack of information about concrete research-based interventions and practices which could be helpful for delinquent students with EBD to cope with problem behaviour more effectively. The aim of the study was to assess the emotional and behaviour disorders of girls living in socialization centres and to review intervention strategies for changing behaviour through physical activity.

Methods. The study was conducted in two Children Socialization Centres where 50 girls aged $12-18$ are housed following the decision of Child Welfare Commission. Behaviour Assessment System for Children (BASC-2), a Self-Report Personality Scale was used to find out emotional and behavioural disorders of girls.

Results. Analysis of our study results reveals that the girls with delinquent behaviour living in CSC show the risk of having problems in school, high level of social stress, anxiety, sense of inadequacy, atypicality, attention problems, hyperactivity and lower levels of self-esteem, self-reliance, interpersonal relations. The results support the conclusions of other studies which found significant relations between EBD students and weak levels of social skills, self-esteem and self-efficacy, cooperation.

Conclusion. Sport and physical activity settings are effective intervention setting for creation, practicing and maintenance of pro-social behaviour and emotion managing; furthermore those skills could be transferred to community settings in everyday life. The best education setting for EBD students could be provided in inclusive environment, where the positive behaviour skills could be copied and maintained.
\end{abstract}

Keywords: emotional and behavioural disorders, intervention strategies, delinquent behaviour, restricted environment.

\section{INTRODUCTION}

$\mathrm{S}$ tudents with emotional and behavioural disorders (EBD) represent one of the most challenging groups not only to provide effective educational services, but often present complex challenges for schools, families, and society (Cancio \& Johnson, 2013; Cook, Landrum, Tankersley, \& Kauffman, 2003). Individuals' with EBD usually demonstrated behaviours can be so disruptive that they can seriously complicate relationships with peers, parents, and teachers
(Farrell, Shaw, \& Webber, 2009; Kann, Traci, \& Hanna, 2000). Unfortunately, these children and youth often demonstrate deficits in social skill and this can have profound effects on successful community integration and cooperation (Gendron, Royer, Bertrand \& Potvin, 2004; Gresham, Sugai, \& Horner 2001). Social skills are learned behaviours necessary for individuals to get along successfully with others in both school and community settings (Sheridan, Eagle, Cowan, \& Mickelson, 2001). 
Students identified as having an EBD tend to be less engaged, they are more likely to display off-task behaviours, and are more impulsive, uninvolved, and inattentive, often waste time, accomplish little, and require increased instructional attention and effort from teachers and supervisors, commonly demonstrate non-compliant behaviour that disrupts the class as a whole (Edwards-Duke, Boswell, McGhee, \& Decker, 2002). Typical characteristic of individuals with EBD can be hyperactivity, restlessness, short attention span, and hyperkinesis. They engage in disruptive, destructive, aggressive and defiant behaviours that interfere with the educational progress and impede learning and social interactions, also reduce their self-esteem and self-efficacy (Daniels, 2002; Jolivette, Stichter, \& McCormick, 2002; Szymanski \& Zolotor, 2001)

Researchers have reported that EBDs are predictive of severe long-term difficulties across every aspect of life (Fitzpatrick \& Knowlton, 2009; Scott \& Shearer-Lingo, 2002) and found out disappointing outcomes for students with EBD compared to those without disabilities: higher school dropout rates (Edwards-Duke et al., 2002; Kaufman, Alt, \& Chapman 2001); lower rates of participation in postsecondary education (Wagner, Cameto, \& Newman 2003); higher unemployment levels (Carter \& Wehby 2003); lower rates of community participation (Armstrong, Dedrick, \& Greenbaum 2003; Samalot-Rivera \& Porretta, 2013) delinquency and adult psychiatric problems such as mood disorders, anxiety disorders, antisocial behaviour in adulthood (Edwards-Duke et al., 2002). Historically, students with an EBD mostly were taught in segregated environment as they usually failed in the regular school setting (Cook et al., 2003; Kauffman, 2001; Scott \& Shearer-Lingo, 2002). Over the past few years, seeking to eliminate all forms of discrimination, the idea of including students with disabilities into a general education classroom has become prevalent in many countries (DePauw \& Doll-Tepper, 2000; Hunt \& McDonnell, 2007). The consensus about the concept of inclusive education was found at the 48th session of the International Conference on Education in November 2008 (Conclusions and Recommendations of the $48^{\text {th }}$ session of the International Conference on Education, 2008). This attitude concerns individual with EBD as well, though behaviour disorders still represent a major concern in today's schools. (Jing Qi \& Amy Ha, 2012). Researchers report (Jolivette, et al., 2014; Wagner \& Cameto, 2004;
Wagner, Newnan, Cameto, \& Levine, 2005) that some students with EBD due to their inadequate behaviour (argue with school personnel, fight with others during instructional contexts, do not control their behaviour appropriately in school situations) may receive educational services delivered in more restrictive settings (self-contained class, alternative schools, residential facilities, secure juvenile justice settings). Lehr (2004) found that most states in US are relying on these alternative settings to serve students with EBD and challenging behaviours, as result of this between $33 \%$ and $75 \%$ of students in alternative settings may be identified as having EBD.

According to Lithuanian Statistics (2012), about $80 \%$ of youngsters living in socialization centres are identified as having EBD. According to Lithuanian law, the aim of socialization centres is to improve individuals' prosocial behaviour and living skills, motivation for studies and positive self-esteem. The Report of Prosecution Service of the Republic of Lithuania (2013) and scientific publications (Enzmann et al., 2010; Zahn, Hawkins, Chiancone, \& Whitworth, 2008) state that recently delinquency list becomes more ferocious; a lot of parents cannot cope with the inappropriate behaviour of their children and institutionalize them. According to Fitzpatrick and Knowlton (2009), despite the notable difficulties in translating research findings into effective evidence-based practices, practitioners continue to seek workable, evidence-based interventions that can help students who have an EBD to manage their own behaviour and achieve success with the general education curriculum. Although many existing practices are supported by research evidence, other popular, professionally recommended programs are grounded in little or no research supportive of their use with students identified as having an EBD. In the Report of National Audit Office of Lithuania (2013) it was reported that there is a lack of professionals in those institutions such as psychologists, social and special pedagogues; there is no common evaluation of progress for students with EBD; and there are difficulties in evaluating the efficiency of used intervention programmes, as they are different in each socialisation centre. Korbin et al. (2010) point out that delinquent behaviour of the girls is usually their efforts to understand their own feelings, and the problem really needs attention and studies to find out the reasons of such behaviour, risk factors, possibilities of effective prevention 
and intervention. Girls with EBD avoid being open with their parents, teachers, or other adults. That is why self-report questionnaire could be very helpful for educators to get objective information about the psychological profile of a concrete girl. Additional information is needed about concrete researchbased interventions and practices which could be helpful for delinquent students with EBD to cope more effectively with problem behaviour.

The aim of the study was to assess the emotional and behaviour disorders of girls living in socialization centres and to review intervention strategies for changing behaviour through physical activity.

\section{METHODS}

Research organization and Participants. The study was conducted in April and March, 2013, in two Children Socialization Centres where 50 girls aged 12-18 are housed following the decision of Child Welfare Commission. Our sample included one 12-year-old, one 18-year-old, two 13 year-old girls, eight 14-year-old girls, eight 17 year-old girls, fifteen 15 and 16 year-old girls. As many as 23 girls came from biological families, 23 girls came from foster homes, and 4 girls lived with foster-parents. The subjects were institutionalized due to absenteeism from school and vagabondage (50 girls), the use of alcohol and psychotropic substances (19 girls), stealing (3 girls), violent and aggressive behaviour (5 girls), and prostitution (1 girl). The permission to carry out the research was signed by the directors of both Children Socialization Centres.

Behaviour Assessment System for Children (BASC-2) (Reynolds \& Kamphaus, 2004) a SelfReport Personality Scale (SRP -A, ages 12 through 18) was used to find out emotional and behavioural disorders of girls. SRP is an omnibus personality inventory consisting of statements that respondents answer in one of two ways. Some of its items require a True or False response, while others call for rating on a four-point scale of frequency, ranging from Never to Almost always. The individual profiles were created for every subject, identifying the strengths and weakness of each participant, and the reports of individual progress were obtained. The SRP takes about 20 to 30 minutes to complete.

The data were processed by means of Behaviour Assessment System for Children Scoring and Reporting System BASC-2 ASSIST ${ }^{\mathrm{TM}}$ Plus(Reynolds \& Kamphaus, 2004). Each program generates profiles, calculates validity indexes, identifies strengths and weaknesses, and computes multirater comparisons and progress reports. The BASC-2 ASSIST ${ }^{\mathrm{TM}}$ Plus offers the additional features of reporting content scales, target behaviours for intervention, and relationships to DSM-IV-TR diagnostic criteria. A descriptive label may be applied to each scale of BASC-2 system and a composite score using the classification system in Table 1 .

Table 1. Scale and composite score classification

\begin{tabular}{|l|l|l|}
\hline \multicolumn{2}{|c|}{ Classification } & \multirow{2}{*}{ T-Score Range } \\
\cline { 1 - 2 } Adaptive scales & \multicolumn{1}{|c|}{ Clinical scales } & \\
\cline { 1 - 2 } Very High & $\begin{array}{l}\text { Clinically } \\
\text { Significant }\end{array}$ & 70 and above \\
\hline High & At-Risk & $60-69$ \\
\hline Average & Average & $41-59$ \\
\hline At-Risk & Low & $31-40$ \\
\hline $\begin{array}{l}\text { Clinically } \\
\text { Significant }\end{array}$ & Very Low & 30 and below \\
\hline
\end{tabular}

According to the classification system (T-score range), it could be determined if the girls' emotions and behaviour are normal or not. If the score is above 60 , the behaviour is determined as risky. Filling in the BASC scale, the attitudes of girls towards emotions, thoughts and perception were detected and divided into two groups, the ones that strengthen delinquency (depression, anxiety, social stress, hyperactivity, aggressiveness, behaviour problems, withdrawal) and those reducing delinquency (good relationship with parents and peers, leadership, self-respect, adaptation, psychological resistance). The data were processed using a Statistical Package for Social Science (SPSS 19.0 for Windows).

\section{RESULTS}

As the number of participants was not big and the girls had quite different emotional and behavioural problems, the average scores of the Emotional Behaviour scale did not show any significant risk, so it was relevant to point out individually how many girls were at risk (Table 2).

The results of our study pointed out that on the Attitude towards School and on the Attitude towards Teachers scales the $\mathrm{T}$ score mean indicated the risk for $20 \%$ of the girls who participated in the study. In this scale Attitude towards School is defined as feelings of alienation, hostility, and dissatisfaction regarding school; Attitude towards Teachers reflects feelings of resentment and dislike of teachers, 


\begin{tabular}{|c|c|c|c|c|}
\hline \multirow{18}{*}{$\begin{array}{l}\text { Table 2. Average scores of the } \\
\text { Emotional Behaviour scale of } \\
\text { girls with delinquent behaviour }\end{array}$} & \multicolumn{2}{|r|}{ Scales } & \multirow{2}{*}{$\begin{array}{c}\text { T Score mean } \\
50.7 \pm 11.59\end{array}$} & \multirow{2}{*}{$\begin{array}{c}\text { Min-Max } \\
35-80\end{array}$} \\
\hline & \multirow{3}{*}{$\begin{array}{l}\text { School Problems } \\
52.94 \pm 10.716\end{array}$} & Attitude to School & & \\
\hline & & Attitude to Teachers & $50.7 \pm 10.61$ & $34-79$ \\
\hline & & Sensation Seeking & $55.2 \pm 10.20$ & $33-79$ \\
\hline & \multirow{7}{*}{$\begin{array}{l}\text { Internalizing Problems } \\
\mathbf{5 8 . 3 6} \pm \mathbf{1 1 . 5 3 3}\end{array}$} & Atypicality & $58.0 \pm 12.29$ & $42-93$ \\
\hline & & Locus of Control & $59.0 \pm 10.01$ & $40-79$ \\
\hline & & Social Stress & $55.0 \pm 11.94$ & $35-90$ \\
\hline & & Anxiety & $57.1 \pm 9.76$ & $34-80$ \\
\hline & & Depression & $57.4 \pm 11.49$ & $40-84$ \\
\hline & & Sense of Inadequacy & $56.24 \pm 11.98$ & $35-82$ \\
\hline & & Somatization & $50.62 \pm 8.13$ & $40-69$ \\
\hline & \multirow{2}{*}{$\begin{array}{l}\text { Inattention/ } \\
\text { Hyperactivity } \\
56.54 \pm 10.544\end{array}$} & Attention problems & $54.64 \pm 10.74$ & $34-79$ \\
\hline & & Hyperactivity & $56.8 \pm 11.96$ & $36-81$ \\
\hline & \multicolumn{2}{|c|}{ Emotional Symptoms Index } & $59.1 \pm 10.81$ & $37-85$ \\
\hline & \multirow{4}{*}{$\begin{array}{l}\text { Personal Adjustment } \\
\mathbf{4 2 . 9 2} \pm \mathbf{1 2 . 1 8 8}\end{array}$} & Relations with Parents & $44.9 \pm 11.45$ & $21-65$ \\
\hline & & Interpersonal Relations & $45.6 \pm 14.19$ & $10-62$ \\
\hline & & Self-Esteem & $39.2 \pm 12.16$ & $16-62$ \\
\hline & & Self-Reliance & $41.9 \pm 10.86$ & $16-58$ \\
\hline
\end{tabular}

beliefs that teachers are unfair, uncaring, or overly demanding. T score mean on Sensation Seeking was indicated risk for $36 \%$ of girls. Evaluating their internalization problems the T score mean signalled risk for 3\% of girls on the Atipicality scale, which means having unusual thoughts and perceptions and the tendency to bizarre or odd thoughts and behaviours. Sense of Inadequacy indicates a relatively high number of feelings of inadequacy, and the child may display or report quitting easily, sense of failure, and $34 \%$ of the girls were at risk. Emotional Symptoms Index results showed the risk for more than $50 \%$ of the girls and the average mean of whole group was $59.1 \pm 10.805$, which shows that the whole group was also at risk. Three of the scales included in the ESI - Social Stress, Anxiety and Depression - may be referred to as the $S A D$ Triad. High scores on the SAD Triad represent significant emotional distress characterized by depression with substantial tension. In general, high scores also reflect the presence of poor support mechanisms or coping skills for life's difficulties. All these three feelings showed risk for $40 \%$ of the girls. Social stress reflects feelings of stress and tension in personal relationships and/or feeling of being excluded from social activities. Anxiety is defined as feelings of nervousness, worry, and fear; the tendency to be overwhelmed by problems, as Depression means feelings of unhappiness, sadness, and dejection, a belief that nothing goes right. Even $18 \%$ of the girls felt some kind of somatization and T score means on Locus of Control scale showed risk for $50 \%$ of girls, and average scores of this feature also showed risk for the whole group of participants. Locus of Control indicates a below-average sense of control, and the child may report being controlled by parents or just as bad things happening. Even $32 \%$ of girls were at risk for hyperactivity and attention problems. Attention Problems indicates problematic levels of paying attention, and the child may report having a short attention span, forgetting things. Hyperactivity reflects the tendency to be overly active, rush through work or activities, and act without thinking. Personal adjustment scale showed the problems for $48 \%$ of girls on selfesteem, and this value was at the lowest limit of the scale, it means that most of the girls demonstrated too low self-esteem. Self-Esteem indicates belowaverage levels of self-esteem, the child may show or report concerns about looks and want to be someone else. The girls (38\%) were at risk for self-reliance and relations with parents. Self-Reliance indicates below-average levels of self-reliance; the child may show or report lack of dependence, difficulty in making decisions. Relations with Parents indicate problematic relationship with parents; the child may show or report lack of trust, not being close with parents. Interpersonal relations were poor for $24 \%$ of the girls. Interpersonal Relations scale reflects the perception of having good social relationships and friendships with peers. Scale scores in the Clinically Significant range suggest a high level of maladjustment. Scores in the At-Risk range may identify to problem that needs careful monitoring. 


\section{DISCUSSION}

Analysis of our study results reveals that the girls with delinquent behaviour living in CSC show the risk of having problems at school, high level of social stress, anxiety, sense of inadequacy, atypicality, attention problems, hyperactivity and lower levels of self-esteem, self-reliance, interpersonal relations. The results support the conclusions of other studies which found significant relations between EBD students and weak levels of social skills, self-esteem and self-efficacy, cooperation (Gendron et al., 2004) and delinquency (Pileckaitè-Markovienè, 2006). In their research Remschmidt and Walter (2010) stress that the first factor for delinquency is a behavioural disturbance in early childhood, such as attention deficithyperactivity disorder (ADHD), aggressiveness, or disturbances of social behaviour, which limit the individual's developmental possibilities. We support the conclusions of Korbin et al. (2010) who point out that delinquent behaviour of the girls is that problem which need to be really perceived, researched trying to find out the reasons of such behaviour, risk factors, possibilities of effective prevention and intervention. We believe that it is very important to determine and evaluate emotional and behaviour problems of girls with delinquency, but it is more important to find out and apply the most effective intervention methods for both changing behaviour and preventing delinquency in adulthood. Research (Salkind, 2002) shows that once a pattern of aggressive, defiant, and impulsive behaviour has been established, it is highly resistant to change. Because of countless repetitions over time, maladaptive patterns of emotion regulation become deeply ingrained by years to the extent that they become core components of a child's personality structure. Moreover, children who show high levels of aggression and other antisocial behaviour or have EBD are more likely to be rejected by their peers and to receive negative attention from teachers, which in turn leads to more aggression. Later on, these children are frequently suspended and/or expelled, begin to fail academically, and develop adversarial relationships with the school system, and by the time these children have had a lifetime of training and preparation for delinquent behaviour in adolescence, they easily find peers who reinforce their patterns of behaviour. One of the strongest findings that we have to stress is that delinquent children associate with and commit many of their offenses in the company of delinquent peers. So if such a child is taken to segregated environment (e.g. CSC), it can lead to reinforcement of aggressive habits and behaviours, as in these segregated/ isolated settings power-assertive discipline strategies are usually used. The question we have to answer is what should be done to stop this perverse cycle? There are many different techniques that can be used to teach and promote youths' use of appropriate social skills. Researchers suggest different intervention programmes - family management, community based, motivation/level systems shaping the behaviour (Cancio \& Johnson, 2013), choice as an intervention (Jolivette, Wehby, Canale, \& Massey, 2001; Kern, Bambara, \& Fogt, 2002), inclusive education and other practices, selfdirected intervention strategies (e.g. selfmanagement, self-monitoring, self-instruction) (Fitzpatrick \& Knowlton, 2009), replacement behaviours and many others. It is equally important that teachers understand that their behaviour not only influences student behaviour, but is itself influenced by student behaviour. A greater understanding of those reciprocal interactions that transcend typical linear models of teaching and learning should strengthen the quality of instruction for students with learning and behaviour problems. One of the main things that we would like to discuss is the importance of applied practices in inclusive settings. As one of the factors for delinquency is internal problems, the other factor are deleterious influences and living environments that make allowance for antisocial behaviour. Skerbetz and Kostewicz (2013) also stress that from an educational perspective, teachers in segregated settings provide fewer positive learning opportunities and less academic growth (Sutherland \& Wehby, 2001) as compared with general education settings. Wagner et al. (2006) point out that peer interaction effects occur when students with ED spend the majority of time with other students with ED. Gunter and Coutinho (1997) described segregated settings for students with ED as negatively reinforcing. Teachers in these settings often maintain a curriculum of non-instruction (Sutherland \& Wehby, 2001); students tend to display learned helplessness behaviours (Sutherland \& Singh, 2004); and together students and teachers partake in a cycle of coercion (Gunter, Denny, \& Venn, 2000). In contrast, students with disabilities educated in inclusive settings have more opportunities for appropriate peer models, for meaningful and appropriate contact with students without special needs; greater expectations placed on academic 
performance and promote the social and educational development of students with EBD (Tapasak \& Walther-Thomas, 1999; Walther-Thomas, Korinek, McLaughlin, \& Williams, 2000). Teachers perceive the inclusion of students with EBD as undesirable mostly because of behavioural concerns (Sutherland $\&$ Singh, 2004), however, the educational climate has seen a change with inclusive practices occurring more often providing more opportunities for students with special needs to receive education together with their nondisabled peers (Burstein, Sears, Wilcoxen, Cabello, \& Spagna, 2004; Snyder \& Dillow, 2011). Problems connected with the integration of children with EBD into regular education system are relevant nowadays not only in Lithuania, but in other countries as well. Students with emotional and behaviour disturbance do not follow the inclusion trend in the same way as other students with disabilities do, and the former group has a greater likelihood to receive segregated instruction as compared with students with learning disabilities, intellectual disabilities, or hearing impairments (Bullock \& Gable, 2006). Evans, Weiss, and Cullinan (2012) point out that in US "The Individuals with Disabilities Education Act" (IDEA 2004) indicated the desirability of an inclusive educational environment for all students with disabilities, including those with emotional disturbance, but recent national data show that only $37 \%$ of students with ED experienced the intended level of inclusion (at least $80 \%$ of the day the child should be taught in regular education classrooms). Although educators declare (Kauffman, 2010) that best educational practice should be more important than any particular educational placement, Zigmond, Kloo, and Volonino (2009) pointed out the significance of where the special education has been implemented. Despite an increasing trend toward more inclusive settings, the researchers (Landrum, Katsiyannis \& Archwamety, 2004) point out that the movement toward less restrictive environments has been far slower than for students with disabilities overall. Other researchers (Cullinan \& Sabornie, 2004; Nelson, Benner, Lane, \& Smith 2004; Wagner, Kutash, Duchnowski, Epstein, \& Sumi, 2005 a) suppose that the interaction between characteristics and educational environment is still not clear. On the other hand, findings (Fekkes, Pijpers, Verloove-Vanhorick, 2006; Skerbetz \& Kostewicz, 2013) show that frequent and active bullying of EDB children at school is associated with delinquent behaviour and carries with it the risk that children may develop an antisocial lifestyle as both personal and environmental factors thus seem to influence the development of EBD, therefore, environmental factors may be used to prevent or reduce characteristics of EBD. Kauffman et al. (2002) suggest that teachers cannot deliver, monitor, and adapt instruction for students with ED with the level of structure and intensity required for general education settings. Therefore, to promote successful inclusive opportunities for students with $\mathrm{EBD}$, it is imperative that teachers are provided with the knowledge and skills that will enable them to develop the most effective academic and behavioural interventions programs for their students.

Physical education and sport offer unique opportunities for students with EBD to learn and exhibit appropriate social skills. Usually students in inclusive settings participate in small or large groups and are expected to socially interact. According to Bruen (2012), engaging in physical activity requires concentration and paying attention to one's bodily movements. Sports such as martial arts, ballet, yoga, dance, or any physical activity that requires deep concentration, memorization, and sequencing of behaviours can help a person to focus their attention. Exercise helps students to cope more effectively with stress, negative affect, stress, anxiety, and depression, as well as self-destructive behaviour, have a more positive identity, and have clearer thought and improved memory (Akande, VanWyk, \& Osagie, 2000; Archer \& Kostrzewa, 2012). There are indications that movement increases mental performance in the parts of the brain involved in memory, attention, spatial perception, language, and emotion, can strengthen learning, motivation and morale (Jensen, 2005; Olsen, 1994). Research show that purposeful exercising with music and dance can increase prosocial behaviour skills, supports cooperation and communication, inhibits aggressive behaviour, social dysfunction, and the most important thing is that learned positive behaviour habits could be transferred to everyday life (Rèklaitiene, 2003). Research by Ostaseviciene, Gaižauskienė, Rèklaitienè, Požèrienè, \& Adomaitienè (2013) identified that educational games for delinquent girls increased such behaviour aspects as decisionmaking, social-interaction, leadership, problemsolving, critical thinking skills and decreased levels of aggression, tension and dissatisfaction. Other evidence indicates that exercise activities used throughout the day can help improve academic performance and reduce disruptive classroom and social behaviour problems (Barkley, Fischer, 
Smallish, \& Fletcher, 2004). Yet the researchers (Hellison, 2003, Rèklaitiene, 2003) stress that while sports and physical education settings offer unique educational experiences where students can act socially, the development of social skills does not happen automatically. According to Buchanan, Flouri, and Brinke (2002), specific instructional strategies need to be used to develop social skills for students with EBD.

\section{CONCLUSION}

Girls with delinquent behaviour usually have emotional and behaviour disorders externalized as high level of social stress, anxiety, sense of inadequacy, atypicality, attention problems, hyperactivity and lower levels of self-esteem, selfreliance, and inter-personal relations. Sport and physical activity settings are effective intervention setting for creation, practicing and maintenance of pro-social behaviour and emotion managing; furthermore those skills could be transferred to community settings in everyday life. The best education setting for EBD students could be provided in inclusive environment, where the positive behaviour skills could be copied and maintained.

Acknowledgments. The research is supported by Research Council of Lithuania. Contract No MIP-112/2012.

\section{REFERENCES}

Akande, A., VanWyk, C., \& Osagie, J. (2000) Importance of exercise and nutrition in the prevention of illness and the enhancement of health. Education, 120(4), 758-72.

Archer, T., \& Kostrzewa, R. M. (2012). Physical exercise alleviates ADHD symptoms: Regional deficits and development trajectory. Neurotoxicity Research, 21(2), 195-209. doi: 10.1007/s12640-011-9260-0

Armstrong, K, Dedrick, R. F., \& Greenbaum, P. E. (2003). Factors associated with community adjustment of young adults with serious emotional disturbances: A longitudinal analysis. Journal of Emotional and Behavioral Disorders, 11, 66-76.

Barkley, R., Fischer, M., Smallish, L., \& Fletcher, K. (2004). Young adult follow-up of hyperactive children: Antisocial activities and drug use. Journal of Child Psychology and Psychiatry, 45(2), 195-211.

Bruen, J. (2012). What are the benefits of physical activity for ADHD? Retrieved from http://www. livestrong.com/article/95374-benefits-physical-activityadhd/\#ixzz2LLrTaaZY

Buchanan, A., Flouri, E., \& Brinke J. A. (2002). Emotional and behavioural problems in childhood and distress in adult life: Risk and protective factors. Australian and New Zealand Journal of Psychiatry, 36(4), 521-527. doi:10.1046/j.1440-1614.2002.01048x

Bullock, L. M., \& Gable, R. A (2006). Programs for children and adolescents with emotional and behavioral disorders in the United States: A historical overview, current perspectives, and future directions. Preventing School Failure, 50(2), 7-13. doi: 10.3200/PSFL.50.2.7-13 Burstein, N., Sears, S., Wilcoxen, A., Cabello, B., \& Spagna, M. (2004). Moving toward inclusive practices. Remedial and Special Education, 25(2), 104-116.

Cancio E. J., \& Johnson J. W. (2013). Designing effective classwide motivation systems for students with emotional and behavioral disorders. Preventing School Failure: Alternative Education for Children and Youth, 57(1), 49-57. doi: 10.1080/1045988X.2012.664582
Carter, E. W., \& Wehby, J. H. (2003). Job performance of transition-age youth with emotional and behavioral disorders. Exceptional Children, 69, 449-465.

Conclusions and Recommendations of the 48th session of the International Conference on Education (ICE). (2008). Retrieved from http://www.ibe.unesco.org/en/ice/48thice-2008/conclusions-and-recommendations.html

Cook, B. G., Landrum, T. J., Tankersley, M., \& Kauffman, J. M. (2003). Bringing research to bear on practice: Effecting evidence-based instruction for students with emotional or behavioral disorders. Education and Treatment of Children, 26, 345-361.

Cullinan, D., \& Sabornie, E. J. (2004). Characteristics of emotional disturbance in middle and high school students. Journal of Emotional and Behavioral Disorders, 12, 157-167.

Daniels, C. D. (2002). Functional behavioural assessment in the general education setting [Electronic version] (Doctoral dissertation, University of Missouri Columbia, 2002). Dissertation Abstracts International, 64, 1706.

DePauw, K. P., \& Doll-Tepper, G. (2000). Toward progressive inclusion and acceptance: Myth or reality? The inclusion debate and bandwagon discourse. Adapted Physical Activity Quarterly, 17, 135-143.

Edwards-Duke, B., Boswell, B., McGhee, S., \& Decker, J. (2002). Creative educational dance and children with behavior disorders: Encouraging a spirit of cooperation. Journal of Dance Education, 2(1), 23-31. doi: 10.1080/15290824.2002.10387203

Evans, C., Weiss, S. L., \& Cullinan, D. (2012). Teacher perceptions and behavioral strategies for students with emotional disturbance across educational environments. Preventing School Failure, 56(2), 1-9. doi:10.1080/104 5988X.2011.574170

Farrell, J. M., Shaw, I. A., \& Webber, M. A. (2009). A schema-focused approach to group psychotherapy for outpatients with borderline personality disorder: 
A randomized controlled trial. Journal of Behavior Therapy and Experimental Psychiatry, 40(2), 317-328. doi:10.1016/j.jbtep.2009.01.002

Fekkes M., Pijpers, F. I., Verloove-Vanhorick, P. (2006). Effects of antibullying school program on bullying and health complaints. Archives of Pediatrics \& Adolescent Medicine, 160(6), 638-644. doi:10.1001/ archpedi.160.6.638.

Fitzpatrick M., \& Knowlton, E. (2009) Bringing evidence-based self-directed intervention practices to the trenches for students with emotional and behavioral disorders. Preventing School Failure, 53(4), 253-266. doi:10.3200/PSFL.53.4.253-266

Gendron, M., Royer, E., Bertrand, R., \& Potvin, P. (2004). Behavior disorders, social competence and physical activities among adolescents. Emotional and Behavioural Difficulties, 9(4), 249-259. doi:10.1177/1363275204050371

Gresham, F. M., Sugai, G., \& Horner, R. H. (2001). Interpreting outcomes of social skills training for students with high-incidence disabilities. Exceptional Children, 67(3), 331-344.

Gunter, P. L., \& Coutinho, M. J. (1997). The growing need to understand negative reinforcement in teacher training programs. Teacher Education and Special Education, 20, 249-264.

Gunter, P. L., Denny, R. K., \& Venn, M. L. (2000). Modification of instructional materials and procedures for curricular success of students with emotional and behavioral disorders. Preventing School Failure, 44(3), 116-121. doi:80/10459880009599793

Hellison, D. (2003). Teaching responsibility through physical activity (2nd ed.). Champaign, IL: Human Kinetics.

Hunt, P., \& McDonnell, J. (2007). Inclusive education. In S. L. Odom, R. H. Horner, M. Snell, \& J. Blacher (Eds.), Handbook on developmental disabilities (pp. 269-291). New York: Guilford Press.

Jensen, E. (2005). Teaching with the brain in mind (2nd ed.). Baltimore, MD: Association for Supervision and Curriculum Development.

Jing, Qi, Amy, S. Ha. (2012) Inclusion in physical education: A review of literature. International Journal of Disability, Development and Education, 59(3), 257281. doi:10.1080/1034912X.2012.697737

Jolivette, K., Wehby, J. H., Canale, J., \& Massey, N. G. (2001). Effects of choice making opportunities on the behavior of students with emotional and behavioral disorders. Behavioral Disorders, 26, 131-145.

Jolivette, K., Stichter, J. P., \& McCormick, K. (2002). Making choices - Improving behavior - Engaging in learning. Teaching Exceptional Children, 34(3) 24-30.

Jolivette, K., Dashaunda P. Patterson, D. P., Swoszowski, N. C., McDaniel, S. Kennedy, C., Ennis, R. P. (2014). School-wide positive behavioral interventions and supports in a residential school for students with emotional and behavioral disorders: First years of implementation and maintenance follow-up focus groups. Residential Treatment for Children \& Youth, 31(1), 63-79. doi:10.1080/088657 1X.2014.878584

Kann, R. T., Traci, R., Hann, F. J, (2000), Disruptive behavior disorders in children and adolescents: How do girls differ. Journal of Counselling \& Development, $78(3)$, 267-274. doi: 10.1002/j.1556-6676.2000. tb01907.x

Kauffman, J. M. (2001). Characteristics of emotional and behavioral disorders of children and youth (7th ed.). Upper Saddle River, NJ: Merrill.

Kauffman, J. M. (2010). Commentary: Current status of the field and future directions. Behavioral Disorders, 35, 180-184.

Kaufman, P., Alt, M. N., \& Chapman, C. D. ( 2001). Dropout rates in the United States 2000. Statistical analysis report. Retrieved from http://nces.ed.gov/ pubs2002/2002114.pdf.

Kern, L., Bambara, L., \& Fogt, J. (2002). Class-wide curricular modifications to improve the behavior of students with emotional or behavioral disorders. Behavioral Disorders, 27, 317-326.

Landrum, T., Katsiyannis, A., \& Archwamety, T. (2004). An analysis of setting and exit patterns of students with emotional or behavioral disorders. Behavioral Disorders, 29(2), 140-153.

Lehr, C. (2004). Alternative schools and students with disabilities: Identifying and understanding the issues. Information Brief, 3(6). Minneapolis, MN: University of Minnesota, Institute on Community Integration. Retrieved from: www.ncset.org/publications/viewdesc. asp? id $=1748$

Lithuanian Statistics. (2012). Retrieved from http:// www.stat.gov.lt

Nelson, J. R., Benner, G. J., Lane, K. L., \& Smith, B. W. (2004). Academic achievement of K-12 students with emotional and behavioral disorders. Exceptional Children, 71, 59-73.

Olsen, E. (1994). Fit kids, smart kids. Parents Magazine, $69,33-35$

Ostasevičienè, V., Gaižauskienè, A., Rèklaitienè, D., Požėrienè, J., Adomaitienè, R., (2013) Changes of negative behaviour in girls as a result of adapted physical education. Spor Bilimleri Dergisi=Hacettepe Journal of Sport Sciences: 19th International Symposium of Adapted Physical Activity "Bridging the Gaps", Istanbul, Turkey, 19-23 July ( pp. 187-190). Ankara: Hacettepe University School of Sport Science and Technology.

Pileckaitė-Markovienè, M., (2006). 16-18 metų delinkventinio elgesio paauglių savivertès ir vidinès darnos ypatumai. Pedagogika, 81, 101-106.

Remschmidt, H., Walter, R. (2010). What becomes of delinquent children? Results of the marburg child delinquency study. Deutsches Arzteblatt International, 107(27), 477-483. doi:10.3238/arztebl.2010.0477

Reynolds, C., \& Kamphaus, R. (2004). BASC-2, Behavior Assessment System for Children, Second edition: Manual. Circle Pines, MN: AGS Publishing. 
Report of Prosecution Service of the Republic of Lithuania. (2013). Retrieved from http://www. prokuraturos.lt/Veikla/Veiklosataskaitos/

Report of National Audit Office of Lithuania. (2013). Retrieved from http://www.vkontrole.lt/en/docs/ Annual_Report_2013_NAOL.pdf

Rèklaitienè, D. (2003). Vidutiniškai protiškai atsilikusiu merginu psichosocialinio elgesio ir fizinio pajegumo kaita dèl aerobikos pratybu poveikio [Rankraštis]: daktaro disertacija. Kaunas: Lietuvos kūno kultūros akademija.

Salkind, N. J. (2002). Child development. Farmington Hills: Cengage Gale Boulder.

Samalot-Rivera, A. \& Porretta, D. L. (2012). The influence of social skills instruction on sport and game related behaviors of students with emotional or behavioral disorders. Physical Education and Sport Pedagogy, 17, 1-16. doi:10.1080./17408989.2011.631004

Scott, T. M., \& Shearer-Lingo, A. (2002). The effects of reading fluency instruction on the academic and behavioral success of middle school students in a selfcontained EBD classroom. Preventing School Failure, 46, 167-174

Sheridan, S. M., Eagle, J. W., Cowan, R. J, Mickelson, W. (2001). The Effects of Conjoint Behavioral Consultation Results of a 4-Year Investigation, Journal of School Psychology, 39(5), 361-385. doi: 10.1016/S00224405(01)00079-6

Skerbetz, M. D., \& Kostewicz, D. E. (2013). Academic choice for included students with emotional and behavioral disorders. Preventing School Failure, 57, 212-222. doi:10.1080/1045988X.2012.701252

Snyder, T. D., \& Dillow, S. A. (2011). Digest of Education Statistics 2010 (NCES 2011-015). National Center for Education Statistics, Institute of Education Sciences, U.S. Department of Education. Washington, DC.

Sutherland, K. S., \& Singh, N. N. (2004). Learned helplessness and students with emotional or behavioral disorders: Deprivation in the classroom. Behavioral Disorders, 29, 169-181.

Sutherland, K. S., \& Wehby, J. H. (2001). The effect of self-evaluation on teaching behaviors in classrooms for students with emotional and behavioral disorders. The Journal of Special Education, 35, 161-171.

Szymanski, M. L. \& Zolotor, A. (2001). Attentiondeficit/hyperactivity disorder: Management. American Family Physician, 64(8), 1355-1362. Retrieved from http://www.aafp.org/afp/2001/1015/p1355.html
Tapasak, R. C., \& Walther-Thomas, C. S. (1999). Evaluation of a first-year inclusion program. Remedial and Special Education, 20(4), 216-225.

The Individuals with Disabilities Education Act (IDEA 2004). Retrieved from: http://www.calstat.org/ publications/article_detail.php?a_id=31\&nl_id=3

Wagner, M., Cameto, R., \& Newman, L. (2003). Youth with disabilities: A changing population. A report of findings from the National Longitudinal Transition Study (NLTS) and the National Longitudinal Transition Study-2 (NLTS2). Executive summary Menlo Park, CA: SRI International.

Wagner, M. \& Cameto, R. (2004). The characteristics, experiences, and outcomes of youth with emotional disturbances. Reports from the National Longitudinal Transition Study, 3(2), 1-8. Retrieved from http://www. neset.org/publications/nlts2/NCSETNLTS2Brief_3.2pdf Wagner, M., Friend, M., Bursuck, W. D., Kutash, K., Duchnowski, A. J., Sumi, W. C., \& Epstein, M. H. (2006). Educating students with emotional disturbances: A National perspective on school programs and services. Journal of Emotional and Behavioral Disorders, 14(1), 12-30.

Wagner, M., Kutash, K., Duchnowski, A. J., Epstein, M. H., \& Sumi, W. C. (2005 a). The children and youth we serve: A national picture of the characteristics of students with emotional disturbances receiving special education. The Journal of Emotional and Behavioral Disorders, 13(2), 79-96.

Wagner, M., Newman, L., Cameto, R., Levine, P. (2005 b). Changes Over Time in the Early Postschool Outcomes of Youth with Disabilities. A Report of Findings from the National Longitudinal Transition Study (NLTS) and the National Longitudinal Transition Study-2 (NLTS2). Menlo Park, CA: SRI International. Retrieved from: www.nlts2.org/reports/2005_06/nlts2 report_2005_06_complete.pdf

Walther-Thomas, C., Korinek, L., McLaughlin, V. L., \& Williams, B. (2000). Collaboration for inclusive education: Developing successful programs. Needham Heights, MA: Allyn \& Bacon

Zahn, M., Hawkins, S. R., Chiancone, J., \& Whitworth, A. (2008). The Girls Study Group-Charting the way to delinquency prevention for girls. Department of Justice, Office of Justice Programs, Office of Juvenile Justine and Delinquency Prevention. Retrieved from http:// www.rti.org/publications/abstract.cfm?pubid=13945

Zigmond, N., Kloo, A., \& Volonino, V. (2009). What, where, how? Special education in the climate of full inclusion. Exceptionality, 17, 189-204.
Corresponding author Jūratė Požèrienė Lithuanian Sports University Sporto str. 6, LT-44221 Kaunas Lithuania Tel. +370 $37302660,+37061448487$ E-mail jurate.pozeriene@1su.1t 